Quim. Nova, Vol. 35, No. 2, 408-410, 2012

\title{
A VALIDATED METHOD USING RP-HPLC FOR QUANTIFICATION OF RESERPINE IN THE BRAZILIAN TREE Rauvolfia sellowii MÜLL. ARG. (APOCYNACEAE)
}

\author{
Leopoldo C. Baratto*, Francinete Ramos Campos, Roberto Pontarolo e Cid A. de Moraes Santos \\ Departamento de Farmácia, Universidade Federal do Paraná, Av. Pref. Lothário Meissner, 632, 80210-170 Curitiba - PR, Brasil
}

Recebido em 26/4/11; aceito em 13/7/11; publicado na web em 19/8/11

\begin{abstract}
This study describes a simple, fast and reproducible method using RP-HPLC-UV, in a gradient system, for quantification of reserpine in Rauvolfia sellowii stem bark. The analysis were carried out on a C18 column; mobile phase was water and acetonitrile, and separations were carried out in $10 \mathrm{~min}$, flow rate of $1.0 \mathrm{~mL} \mathrm{~min}^{-1}, 25^{\circ} \mathrm{C}$ and $268 \mathrm{~nm}$. The validation data showed that the method was specific, accurate, precise and robust. Results were linear over a range of $0.625-40.0 \mu \mathrm{g} \mathrm{mL}^{-1}$, and the mean recovery was $95.1 \%$. The amount of reserpine found in the dried stem bark was $0.01 \%(\mathrm{~m} / \mathrm{m})$.
\end{abstract}

Keywords: liquid chromatography; indole alkaloids; quality control and validation.

\section{INTRODUCTION}

In recent years, medicinal plants and phytopharmaceutical products are more widely used worldwide. New policies have thus emerged to focus on promoting the use of herbal products and to develop useful analytical methods for quality control of these products to guarantee their safety and efficacy. ${ }^{1,2}$ To ensure that a new analytical method can provide reliable and reproducible data, it must be validated accordingly official documents and regulatory agencies that will establish many validation parameters. ${ }^{3}$

The Rauvolfia genus, which is part of the Apocynaceae family, is mainly found across South America and most commonly in Brazil. ${ }^{4}$ This species contains many indole alkaloids, ${ }^{5}$ which are pharmacologically active. ${ }^{4,6-12}$ The popularity of reserpine (Figure 1) during the 1950s, isolated for the first time from $R$. serpentina, aroused great interest and led to investigations of another species in the same genus, ${ }^{13}$ such as Rauvolfia sellowii Müll. Arg.<smiles>COc1ccc2c3c([nH]c2c1)[C@H]1CCN3C[C@@H]2C[C@H](OC(=O)c3cc(OC)c(OC)c(OC)c3)[C@@H](OC)[C@@H](C(C)=O)[C@H]2C1</smiles>

Figure 1. Reserpine

Rauvolfia sellowii, popularly known as "pau-pra-tudo", is a Brazilian native tree. Its leaves, stems and stem bark are traditionally used to reduce glucose and blood cholesterol levels. ${ }^{4,14,15}$ Its roots are used as an anti-hypertensive drug. ${ }^{16}$ Hydroalcoholic extract from stem bark showed anti-inflammatory and antioxidant effects. ${ }^{17,18}$ Many indole alkaloids such as sellowiine and 12-demethoxy-tabernulosine are found in the leaves, ${ }^{16}$ while reserpine, ajmaline and ajmalicine are found in the roots and bark. ${ }^{19,20}$

Since reserpine is present in almost all species of Rauvolfia, ${ }^{6}$ it can be considered a chemical marker of this genus. A method that can identify and quantify this indole alkaloid will be a useful way

\footnotetext{
*e-mail: leopoldo@ufpr.br
}

to guarantee the quality and authenticity of this species. Moreover, reserpine is easily found and less expensive than other indole alkaloid standards. Some methods using HPLC for quantification of reserpine in Rauvolfia species such as $R$. serpentina $a^{21}$ and $R$. verticillata, ${ }^{22}$ and also in biological samples, ${ }^{23,24}$ were recently developed, but the times of the analysis are much longer than the method described in this work.

The aim of this work is to develop a method using high performed liquid chromatography (HPLC) to quantify reserpine found in the stem bark of $R$. sellowii and its derivative extract. To date, this plant has not been studied using HPLC. The method used was validated by regulation RE 899/2003, National Health Surveillance Agency, Brazil ${ }^{25}$ and ICH guidelines. ${ }^{26}$ The following validation characteristics were assessed: selectivity and specificity, linearity, limit of detection and quantification, precision, accuracy and robustness.

\section{EXPERIMENTAL}

\section{Plant material}

Stem bark of $R$. sellowii Müll. Arg., Apocynaceae, was collected in January 2009, in the city of Curitiba, state of Paraná, Brazil (25 26' $\mathrm{S} ; 4^{\circ} 16^{\prime} \mathrm{O}$; at an elevation of $\left.923 \mathrm{~m}\right)$. The species was identified by a biologist, O. dos S. Ribas, and a voucher specimen was deposited in the herbarium of the Botanical Museum of Curitiba under registration MBM 348509.

\section{Chemical and reagents}

Reserpine (Fluka, St. Louis, MO, USA) of the highest grade (purity $>99 \%$ ) was used as an external standard. Acetonitrile (J.T. Baker, Mexico) and methanol (Tedia, USA) were of LC grade. The reagents, triethylamine (Biotec, Brazil), sulfuric acid $\left(\mathrm{H}_{2} \mathrm{SO}_{4}\right.$; Merck, Germany), phosphoric acid $\left(\mathrm{H}_{3} \mathrm{PO}_{4}\right.$; J.T. Baker), formic acid $\left(\mathrm{CH}_{2} \mathrm{O}_{2}\right.$; J.T. Baker), ammonium hydroxide $\left(\mathrm{NH}_{4} \mathrm{OH}\right.$; Vetec, Brazil), sodium bicarbonate ( $\mathrm{NaHCO}_{3}$; Quimex, Brazil), ethyl alcohol (Dinâmica, Brazil) and chloroform $\left(\mathrm{CHCl}_{3}\right.$; Dinâmica) were of analytical grade. Water was purified using a Milli-Q system from Millipore (Milford, MA, USA).

\section{Sample preparation and standard solution}

Air-dried $\left(40^{\circ} \mathrm{C}\right)$ and powdered stem bark $(2.50 \mathrm{~g})$ was extracted with $100 \mathrm{~mL}$ of ethyl alcohol $96^{\circ} \mathrm{GL}$ (pH from 8 to 10, adjusted with 
$\mathrm{NH}_{4} \mathrm{OH}$ ) by heating under reflux for $4 \mathrm{~h}$, while protected from light. The extract was filtered, and the residue was extracted again with an additional $100 \mathrm{~mL}$ of ethyl alcohol. The filtrate was concentrated under reduced pressure to $30 \mathrm{~mL}$. To this volume, $100 \mathrm{~mL}$ of $\mathrm{H}_{2} \mathrm{SO}_{4} 0.5 \mathrm{~N}$ $(v / v)$ was added. It was then submitted to a liquid-liquid extraction with five times of $\mathrm{CHCl}_{3}$, discarding the acidic aqueous phase at the end. The chloroform layer was then extracted four times with $\mathrm{NaHCO}_{3} 2 \%$ $(\mathrm{m} / \mathrm{v})$, discarding the aqueous phase. The resulting chloroform phase $(0.327 \mathrm{~g})$ was evaporated under reduced pressure, and a sample solution of $1.0 \mathrm{mg} \mathrm{mL}^{-1}$ was prepared with $60.50 \mathrm{mg}$ of this chloroform phase, in triplicate, diluted in methanol:acetonitrile $(1: 1, v / v)$.

A stock solution of the reserpine standard $\left(1.0 \mathrm{mg} \mathrm{mL}^{-1}\right)$ was prepared in methanol:acetonitrile $(1: 1, v / v)$. The stock solution was then diluted to obtain a working solution $\left(100.0 \mu \mathrm{g} \mathrm{mL}^{-1}\right)$, which was used to prepare calibration standard solutions at seven different concentrations: $0.625,1.25,2.5,5.0,10.0,20.0$ and $40.0 \mu \mathrm{g} \mathrm{mL}^{-1}$.

All solutions were filtered through Millipore Millex PVDF 0.45 $\mu \mathrm{m}$ filters prior to HPLC injection.

\section{HPLC analysis}

Chromatographic analysis were performed on an Agilent 1100 LC system, consisting of a G1311A quaternary pump, a G1379A degasser, a G1329A automatic injector, a G1315B DAD (Germany), and software ChemStation ${ }^{\circledR}$ version A.10.02.

The analysis were carried out on a Waters (Ireland) Spherisorb ODS2 C18 column ( $250 \mathrm{~mm} \times 4.6 \mathrm{~mm}, 5 \mu \mathrm{m})$. The mobile phase consisted of water $\left(0.1 \% \mathrm{CH}_{2} \mathrm{O}_{2}\right.$ and $0.1 \%$ triethylamine; $\mathrm{pH}=5.0$, adjusted with $\mathrm{NH}_{4} \mathrm{OH}$ and $\left.\mathrm{H}_{3} \mathrm{PO}_{4}\right)$ as solvent $\mathrm{A}$ and acetonitrile $(0.1 \%$ $\mathrm{CH}_{2} \mathrm{O}_{2}$ and $0.1 \%$ triethylamine) as solvent $\mathrm{B}$. Both solvents were filtered through a Millipore PTFE $0.45 \mu \mathrm{m}$ membrane. Separations were carried out using a linear gradient as follows: 0 min $50 \% \mathrm{~B}, 3$ $\min 50 \%$ B, $3.10 \min 55 \%$ B, 6 min $55 \%$ B, $6.10 \min 100 \%$ B, 7 min $100 \% \mathrm{~B}, 7.10 \mathrm{~min} 50 \% \mathrm{~B}$, and $10 \mathrm{~min} 50 \% \mathrm{~B}$. The flow rate of the mobile phase was $1.0 \mathrm{~mL} \mathrm{~min}^{-1}$, and the injection volume was $20 \mu \mathrm{L}$. Chromatographic runs were carried out at $25{ }^{\circ} \mathrm{C}$. UV detection was performed at $268 \mathrm{~nm}$.

\section{Validation studies}

\section{Linearity and range}

To determine the linear relationship between peak area and concentration of reserpine, a concentration range of $0.625-40.0 \mu \mathrm{g} \mathrm{mL}^{-1}$ was tested. Seven different concentrations of the standard were analyzed in triplicate, generating respective calibration curves. The linearity equations were calculated using linear regression analysis, with Origin Pro 8 and Microsoft Office Excel 2007.

\section{Selectivity/specificity}

To verify the purity of the reserpine peak in the $R$. sellowii extract, a DAD detector and the software ChemStation ${ }^{\circledR}$ version A.10.02 were used to analyze its purity.

\section{Limit of detection (LOD) and limit of quantification ( $L O Q)$}

The LOD and LOQ were calculated based on the standard deviation of the $y$-intercept $(\sigma)$ and slope of the calibration curve $(S)$, obtained from linear regression. LOD was calculated using the expression 3.3 $\sigma / S$, and LOQ was calculated using $10 \sigma / S$.

\section{Accuracy}

The accuracy of the method was measured using an analyte recovery test. The working solution of the reserpine standard was added to the diluted matrix sample (R. sellowii extract) in triplicate. Concentra- tions of $1.25,5.0$ and $10.0 \mu \mathrm{g} \mathrm{mL}^{-1}$ of the reserpine standard were used.

\section{Precision}

Repeatability (intra-day) and intermediate precision (inter-day) were determined through analysis of the reserpine standard solution at $100 \%\left(10.0 \mu \mathrm{g} \mathrm{mL}^{-1}, n=6\right)$. The peak areas and retention times were recorded, and the \%RSD (relative standard deviation) was determined. The intermediate precision was determined over a period of 2 days, with different analysts.

\section{Robustness}

The robustness of the method, which is related to the variation of peak areas and retention times, was evaluated based on established conditions. Using three individual injections of the reserpine standard solution at $100 \%$, the column temperature $\left(20\right.$ and $\left.30^{\circ} \mathrm{C}\right)$ and $\mathrm{pH}$ value of the mobile phase-solvent A (4.9 and 5.1) were varied. The results were evaluated by Student's $t$ test $(\alpha=0.05 \%)$.

\section{RESULTS AND DISCUSSION}

A previously reported gradient method to separate and quantitate strictosamide in a Rubiaceae species ${ }^{27}$ was optimized, evaluating parameters such as gradient, amount of organic solvent, $\mathrm{pH}$ value of the mobile phase, flow rate and column temperature. The mobile phase of the original method consisted of water (A) and acetonitrile (B), both with $0.2 \%$ diethylamine and $0.16 \% \mathrm{CH}_{2} \mathrm{O}_{2}$, and the method was carried out in a timeframe of $25 \mathrm{~min}$. To separate and quantitate reserpine in $R$. sellowii extract, a longer timeframe of $60 \mathrm{~min}$ was required. The percentages of diethylamine and $\mathrm{CH}_{2} \mathrm{O}_{2}$ were assessed, and it was found that $0.1 \%$ of each of the two solvent additives was optimal. When diethylamine was replaced with triethylamine, better resolution of the peaks was observed. The $\mathrm{pH}$ value of solvent $\mathrm{A}$ was altered to 5.0. According to official monographs ${ }^{28,29}$ and spectrum data, reserpine was detected with high selectivity at $268 \mathrm{~nm}$. The gradient system was changed to a timeframe of $10 \mathrm{~min}$. The HPLC separation profile of the R. sellowii stem bark extract is shown in Figure 2.

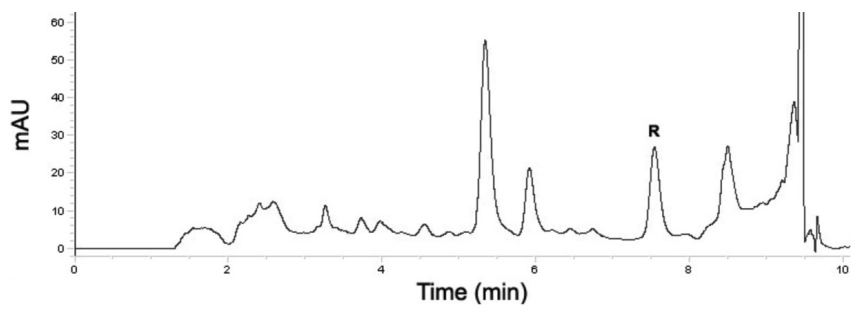

Figure 2. Typical chromatogram obtained from $\mathrm{R}$. sellowii extract. Reserpine $(R)$ retention time in $7.5 \mathrm{~min}$

The method showed a satisfactory separation of the reserpine peak in the $R$. sellowii extract, with good resolution within a short timeframe. The calibration curve was linear over the proposed range, as shown by a linear regression coefficient greater than $0.999(n=7)$. The sensitivity of the method for reserpine was expressed by LOD and LOQ (Table 1).

The peak purity, obtained by DAD detector analysis, was in good agreement with the high spectral purity standard compound.

Recovery of reserpine in the spiked sample was evaluated at three different concentrations: 1.25, 5.0 and $10.0 \mu \mathrm{g} \mathrm{mL}^{-1}$. Recoveries of 95.8 , 91.4 and $98.1 \%$, respectively, were achieved, with a mean recovery of $95.1 \%$ and $\%$ RSD of $3.6 \%$. The method showed satisfactory accuracy, considering the complexity of the method and the extract and the low levels of reserpine added.

The results of the mean peak areas and retention times obtained from the precision analysis are listed in Table 1 . The data showed that 
Table 1. Method validation parameters for quantification of reserpine: linearity, sensitivity, precision and robustness

\begin{tabular}{|c|c|c|c|}
\hline \multicolumn{4}{|l|}{ Linearity regression data ${ }^{\mathrm{a}}$} \\
\hline \multicolumn{2}{|l|}{ Parameters } & \multicolumn{2}{|c|}{ Results } \\
\hline \multicolumn{2}{|l|}{ Linear range, $\mu \mathrm{g} \mathrm{mL}^{-1}$} & \multicolumn{2}{|c|}{$0.625-40.0$} \\
\hline \multicolumn{2}{|l|}{$n$} & \multicolumn{2}{|l|}{7} \\
\hline \multicolumn{2}{|l|}{ Slope $(a)$} & \multicolumn{2}{|c|}{30.84} \\
\hline \multicolumn{2}{|l|}{ Standard deviation of slope } & \multicolumn{2}{|c|}{0.14} \\
\hline \multicolumn{2}{|l|}{ Intercept $(b)$} & \multicolumn{2}{|c|}{-3.78} \\
\hline \multicolumn{2}{|c|}{ Standard deviation of intercept } & \multicolumn{2}{|c|}{2.54} \\
\hline \multicolumn{2}{|l|}{ Correlation coefficient $(r)$} & \multicolumn{2}{|c|}{0.9999} \\
\hline \multicolumn{2}{|l|}{ Limit of detection $\left(\mu \mathrm{g} \mathrm{mL}^{-1}\right)$} & \multicolumn{2}{|c|}{0.272} \\
\hline \multicolumn{2}{|c|}{ Limit of quantification $\left(\mu \mathrm{g} \mathrm{mL}^{-1}\right)$} & \multicolumn{2}{|c|}{0.822} \\
\hline \multicolumn{4}{|l|}{$\underline{\text { Precision studies data }}$} \\
\hline Parameters & Conditions & $P A^{\mathrm{b}} \pm \% \mathrm{RSD}$ & $t_{R}^{\mathrm{c}} \pm \% \mathrm{RSD}$ \\
\hline \multirow[t]{2}{*}{ Repeatability } & Run 1 & $316.14 \pm 0.13$ & $7.52 \pm 0.042$ \\
\hline & Run 2 & $316.14 \pm 0.073$ & $7.53 \pm 0.082$ \\
\hline \multirow[t]{2}{*}{ Intermediate precision } & Day 1 & $317.67 \pm 0.12$ & $7.56 \pm 0.14$ \\
\hline & Day 2 & $320.80 \pm 0.91$ & $7.57 \pm 0.12$ \\
\hline \multicolumn{4}{|l|}{ Robustness studies data } \\
\hline Parameters & Conditions & $P A^{b} \pm \%$ RSD & $t_{R}^{c} \pm \% \mathrm{RSD}$ \\
\hline \multirow[t]{2}{*}{ Temperature } & $20^{\circ} \mathrm{C}$ & $328.27 \pm 2.49$ & $8.07 \pm 4.43$ \\
\hline & $30^{\circ} \mathrm{C}$ & $316.92 \pm 0.0072$ & $7.38 \pm 1.86$ \\
\hline \multirow[t]{2}{*}{$\mathrm{pH}$} & $\mathrm{pH}=4.9$ & $317.31 \pm 0.095$ & $7.55 \pm 0.25$ \\
\hline & $\mathrm{pH}=5.1$ & $316.80 \pm 0.019$ & $7.54 \pm 0.41$ \\
\hline Established conditions $^{\mathrm{d}}$ & & $316.89 \pm 0.15$ & $7.58 \pm 0.60$ \\
\hline
\end{tabular}

a. $\mathrm{y}=\mathrm{ax}+\mathrm{b}$, where $x$ is the concentration of reserpine and $y$ is the peak area; b. $P A$, mean peak areas; ${ }^{\text {c. }} t_{R}$, mean retention times, $\min ;{ }^{\text {d. }} 25^{\circ} \mathrm{C}, \mathrm{pH}=5.0$

the method had good precision, giving \%RSD values of less than $1 \%$.

The robustness of the method was evaluated by changing the colu$\mathrm{mn}$ temperature and $\mathrm{pH}$ value (Table 1 ). Changing $\mathrm{pH}$ values slightly was found to be insignificant to the method. The method carried out at $20{ }^{\circ} \mathrm{C}$ showed significant differences in peak areas and retention times compared to established conditions, as analyzed by Student's $t$ test $(n=$ 3 ) and \%RSD; a \%RSD of more than $1 \%$ indicates low repeatability of the method. The established conditions $\left(25^{\circ} \mathrm{C}\right.$ and $\left.\mathrm{pH}=5.0\right)$ gave acceptable resolution, lower analysis time and more symmetrical peaks.

The concentration of reserpine found in the extract of $R$. sellowii stem barks $\left(1000 \mu \mathrm{g} \mathrm{mL}^{-1}\right)$ using this validated method was $0.757 \mu \mathrm{g}$ $\mathrm{mL}^{-1}$. This corresponds to $0.075 \%(\mathrm{~m} / \mathrm{m})$ in dry matter. The amount of reserpine found in the dried stem bark was $0.01 \%(\mathrm{~m} / \mathrm{m})$.

\section{CONCLUSIONS}

This paper presents a fast, specific, linear, precise, accurate and robust HPLC method for separation and quantitative analysis of reserpine in $R$. sellowii stem bark. It is expected to be a useful tool to guarantee the quality and authenticity of this plant and its derivative products.

\section{ACKNOWLEDGMENTS}

L. C. Baratto and C. A. M. Santos would like to thank CAPES (Coordenação de Aperfeiçoamento de Pessoal de Nível Superior) and CNPq (Consellho Nacional de Pesquisa), respectively, for financial support. We would also like to thank M. da G. T. Toledo and J. C. Gasparetto for technical support.

\section{REFERENCES}

1. Ministério da Saúde, Agência Nacional de Vigilância Sanitária
(ANVISA), Brasil; Decreto n ${ }^{\circ}$. 5813, de 22 de junho de 2006, aprova a Política Nacional de Plantas Medicinais e Fitoterápicos e dá outras providências, http://portal.saude.gov.br/portal/arquivos/pdf/ Decreto_N_5813.pdf, accessed May 2009.

2. WHO; Quality control methods for medicinal plant materials, World Health Organization: Geneva, 1998.

3. Ribani, M.; Bottoli, C. B. G.; Collins, C. H.; Jardim, I. C. F. S.; Melo, L. F. C.; Quim. Nova 2004, 27, 771.

4. Koch, I.; Doctoral Thesis, Universidade Estadual de Campinas, Brazil, 2002.

5. Mandinaveitia, A.; Valencia, E.; Bermejo, J.; Gonzales, A. G.; Biochem. Syst. Ecol. 1995, 23, 877.

6. Carlos, L. A.; Doctoral Thesis, Universidade Estadual do Norte Fluminense Darcy Ribeiro, Brazil, 2007.

7. Pesewu, G. A.; Cutler, R. R.; Humber, D. P.; J. Ethnopharmacol. 2008, 116,102

8. Rastogi, N.; Abaul, J.; Goh, K. S.; Devallois, A.; Philogéne, E.; Bourgeois, P.; FEMS Immunol. Med. Mic. 1998, 20, 267.

9. Tona, L.; Kambu, K.; Ngimbi, N.; Cimanga, K.; Vlietinck, A. J.; J. Ethnopharmacol. 1998, 61, 57 .

10. Kato, L.; Doctoral Thesis, Universidade Estadual de Campinas, Brazil, 2001.

11. Quintans-Júnior, L. J.; Silva, D. A.; Siqueira, J. S.; Souza, M. F. V.; Almeida, R. N.; Silva-Júnior, R. G. C.; Rev. Bras. Farmacogn. 2007, 17, 176.

12. Campbell, J. I. A.; Mortensen, A.; Molgaard, P.; J. Ethnopharmacol. 2006, 104, 379

13. Hochstein, F. A.; Murai, K.; Boegemann, W. H.; J. Am. Chem. Soc. 1955, 77,3551

14. Rech, S. B.; Batista, C. V. F.; Schripsema, J.; Verpoorte, R.; Henriques, A. T.; Plant Cell Tiss. Org. 1998, 54, 61.

15. Silva, G. L. C.; Gaertner, P.; Marson, P. G.; Schwarz, E. A.; Santos, C. A. M.; Lat. Am. J. Pharm. 2004, 23, 148.

16. Batista, C. V. F.; Schripsema, J.; Verpoorte, R.; Rech, S. B.; Henriques, A. T.; Phytochemistry 1996, 41, 969.

17. Presibella, M. M.; Santos, C. A. M.; Weffort-Santos, A. M.; Rev. Bras. Farmacogn. 2003, 13, 75.

18. Menezes, P. R.; Schwarz, E. A.; Santos, C. A. M.; Fitoterapia 2004, 75, 398.

19. Hochstein, F. A.; J. Am. Chem. Soc. 1955, 77, 5744.

20. Pakrashi, S. C.; Djerassi, C.; Wasicky, R.; Neuss, N.; J. Am. Chem. Soc. 1955, 77, 6687 .

21. Goel, M. K.; Mehrotra, S.; Kukreja, A. K.; Shanker, K.; Khanuja, S. P. S. Em Methods in Molecular Biology, Protocols for In Vitro Cultures and Secondary Metabolite Analysis of Aromatic and Medicinal Plants; Jain, S. M.; Saxena, P. K., eds.; Humana Press: New York, 2009, cap. 2.

22. Hong, B.; Cheng, W.; Wu, J.; Zhao, C.; Chromatographia 2010, 72, 841.

23. Li, H.; He, J.; Liu, Q.; Huo, Z.; Liang, S.; Liang, Y.; Ito, Y.; Chromatographia 2011, 73, 171.

24. Li, H.; He, J.; Liu, Q.; Huo, Z.; Liang, S.; Liang, Y.; J. Sep. Sci. 2011, 34, 542 .

25. Ministério da Saúde, Agência Nacional de Vigilância Sanitária (ANVISA), Brasil; Resolução-RE nº. 899, de 20 de maio de 2003, Guia para validação de métodos analíticos e bioanalíticos, http://www.anvisa. gov.br/legis/resol/2003/re/899_03re.htm, accessed May 2009.

26. ICH; Validation of Analytical Procedures: Text and Methodology Q2(R1), International Conference on Harmonisation (ICH) of Technical Requirements for Registration of Pharmaceuticals for Human Use, Geneve, 2005.

27. Dhooghe, L.; Mesia, K.; Kohtala, E.; Tona, L.; Pieters, L.; Vlietinck, A. J.; Apers, S.; Talanta 2008, 76, 462.

28. The United States Pharmacopoeia; $30^{\text {th }}$ revision - National Formulary $25^{\text {th }}$, published on CD-ROM, 2007

29. British Pharmacopoeia; $5^{\text {th }}$ edition, published on CD-ROM, 2007. 